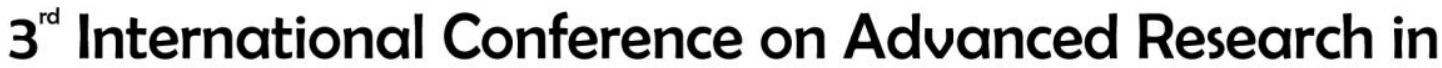 SOCIAL SCIENCES
}

11-14 March, 2021

Oxford - United Kingdom

\section{The Perceived Attitude of Restaurant Applications Users in Bogotá City, Colombia}

\author{
Gerson Jaquin Cristancho-Triana ${ }^{1 *}$, Alfonso Cancino-Gómez ${ }^{2}$, Campo Elías López- \\ Rodríguez $^{3}$, Fernando Augusto Poveda-Aguja ${ }^{4}$ \\ ${ }^{1}$ Leader of the research observatory Consumption Lab. Research professor of the Marketing and \\ Advertising, Universidad ECCI, Colombia \\ ${ }^{2}$ Leader of the research line in consumer and marketing management. Research professor of the \\ Marketing and Advertising Universidad ECCI, Colombia \\ ${ }^{3}$ Research professor of the International Trade, Universidad ECCI, Colombia \\ ${ }^{4}$ Research professor of the Master of Education, Corporación Universitaria Minuto de Dios \\ - UNIMINUTO, Colombia \\ *Corresponding author
}

\begin{abstract}
Consider the aspects contemplated by mobile app users when ordering prepared food, this research aims to understand the consumer's perceived attitude of home applications through a multi-attribute model and the relationship between factors about the most perceived applications. This research is based on attitude theory through a multi-attribute model that measures the judgment of value and experience towards a brand by the current and potential consumer. The degree of association between the social classes of the population studied and the factors affecting the use of applications for purchases or home services were identified through bivariate correlations through Spearman's Rho statistic. The results show that the longest-time brands in the market have a better perception of the consumer; however, the brands with the highest perceived attitude have a weak relationship between the social classes and the factors that affect the use of home applications. The research allowed make an assessment through the attributes perceived by the consumer towards the most used applications, comparing their performance level from a general measurement of the category; In this way, the perception by consumers is identified to strengthen the value proposition by the organizations that use these technological platforms.
\end{abstract}

Keywords: Consumption, perceived attitude, mobile applications, home services.

\section{Introduction}

The greatest daily use of mobile phones (Kim et al. 2008; Zuki 2011; Rivera et al. 2015) and its increasing incursion rate of $127.3 \%$ (MinTic 2018) in Colombia, the development of applications for phones, the advancement of mobile marketing (Wang, Lin \& Luarn 2006), an user increasingly immersed in modern communication technologies and the easiness of online services, the benefits of this technology related to reducing communications costs, lower administrative costs and facilities to disseminate data (Rivera et al. 2015) or factors such as an fast pace of life or schedules that accentuate the lack of time (Pigatto et al. 2017) have triggered lifestyle changes (Sjahroeddin 2018) that promotes the development and growth of solutions that facilitate consumer comfort, including home services through applications or web portals. AMSDMR multi-restaurant home services mobile applications are recent in Colombia; the Domicilios.com app was the pioneer that entered the country in 2007, followed in 2015 by 


\section{$3^{\text {td }}$ International Conference on Advanced Research in SOCIAL SCIENCES}

11-14 March, 2021

Oxford - United Kingdom

Rappi, by 2016 comes to the country Uber Eats and finally IFood starts operations in 2018 (Institutional Colombia, s.f.) quickly developed a new market. AMSDMRs provide delivery services to multiple restaurants in both restaurant chains and local units (Ray et al. 2019), which act as a cross-cutting intermediary network (Kung \& Zhong 2017), offering its clients a wide range of options, ratings, comments, and access to various means of payment (He et al. 2019). These differ from other home applications in that the chains have their exclusive applications for delivery activities (Yeo et al. 2017) and through them implement actions to promote sales of the specific brand; but it is the AMSDMRs that have attracted the attention of different audiences such as investors, entrepreneurs and researchers for the different effects that these applications have generated on society and especially by the continuing increased revenue as seen in Table 1, and their rapid growth of online shopping (Pendrous 2006) that demonstrate the success of these business models in the world.

Table 1. Data from AMSDMR *

\begin{tabular}{lllll}
\hline Data & Domicilios.com & Rappi & Uber Eats & I Food \\
\hline Restaurants & 8.000 & 4.000 & 2.500 & 4.000 \\
Ranges & 3 countries & 7 countries & 13 countries & ND \\
Ingress & $61 \%$ & $43 \%$ & $22 \%$ & ND \\
Incomes 2018 & $\$ 28.522$ million pesos & $\$ 77,227$ million pesos & ND $* *$ & ND \\
\hline
\end{tabular}

Note: * Figures may vary from different sources. ** Not available.

Source: Own elaboration based in La República (2018), Dinero (2019) y El Tiempo (2019).

From the field of consumer behavior associated with the use of online shopping applications and delivery apps, the interest has been oriented to the study of motivations to use an AMSDMR (Ray et al. 2019), the perception of service in the distribution of food online (Sjahroeddin 2018), behavior (Yeo et al. 2017; Elvyari et al. 2017; He et al. 2019) consumer attitudes (Yeo et al. 2017), the effects of quality of service on consumer attitudes (Moon \& Armstrong 2019), risk perception in purchases through digital media (Sanchez-Alzate \& Montoya-Restrepo 2016; Kim et al. 2008, Moon \& Armstrong, 2019; Bhatnagar et al. 2000) and customer satisfaction (Zuki 2011).

From an economic perspective, the commercial impact of AMSDMR concerning companies' performance (Pigatto et al. 2017), the agents of the value chain (He et al. 2019), the aspects that affect the purchase of food online (Daim et al. 2013), as well as the implications of the design of the application or web portal (Huang et al. 2007).

A user's acceptance, rejection, and motivation to use towards an AMSDMR is determined by the attitudes expressed by users, as well as a positive attitude towards technology or the beliefs of the benefits of technology encourages the adoption and use of a mobile application (Pigatto et al. 2017), also owing on its use, the perception of risk (Kim et al. 2008), in this regard, background investigations have not measured the effect of users' attitudes towards the selection and use of an AMSDMR.

The changes also bring with them a new type of consumer, which according to Straus and Frost (2012, quoted by Pigatti et al. 2017) is multifaceted, non-identifiable and also does not remain on a website for long, in some cases, the consumer lack of confidence in digital media makes it difficult to buy in these media (Sánchez-Alzate \& Montoya-Restrepo 2016). Therefore, the motivation for the use of an ASDMR is the result of the assessments of several factors that trigger attitudes towards applications, given the involvement of attitudes in consumer selection, those aspects are related in Table 2. 


\section{$3^{\text {rd }}$ International Conference on Advanced Research in SOCIAL SCIENCES}

11-14 March, 2021

Oxford - United Kingdom

Table 2. Appearance or factors that affect the use of applications for purchases or home services through web and mobile portals.

\begin{tabular}{|c|c|c|}
\hline Authors & Variables use motivation & Context \\
\hline $\begin{array}{l}\text { Bhatnagar, Misra \& Rao } \\
(2000)\end{array}$ & $\begin{array}{l}\text { Risk Perception, Financial Risk } \\
\text { Risk to the product, Risk to information }\end{array}$ & Online shopping behavior \\
\hline Wang et al. (2006) & $\begin{array}{l}\text { Self-efficacy, Financial resource perceived } \\
\text { Perceived utility. Perceived ease of use. Perceived credibility }\end{array}$ & $\begin{array}{l}\text { Intent towards mobile } \\
\text { marketing behavior }\end{array}$ \\
\hline $\begin{array}{l}\text { Kim,Park \& Morrison } \\
(2008)\end{array}$ & $\begin{array}{l}\text { Experience with technology, Experience with travel, } \\
\text { Perception of utility, Perception regarding ease of use, } \\
\text { Attitude towards mobile technology }\end{array}$ & $\begin{array}{l}\text { Adoption of mobile } \\
\text { technology in tourism } \\
\text { services }\end{array}$ \\
\hline Persaud \& Azhar (2012) & Consumer Shopping Style, Brand Confidence, Value & $\begin{array}{l}\text { Adoption of mobile } \\
\text { marketing }\end{array}$ \\
\hline $\begin{array}{l}\text { Daim, Basoglu, Gunay, } \\
\text { Yildiz \& Gómez (2013) }\end{array}$ & $\begin{array}{l}\text { Utility, Confidence and Accuracy, Information, Response } \\
\text { Time, Complementary Relationships, Image Compatibility, } \\
\text { Health Concern, Social Responsibility }\end{array}$ & Buying food online \\
\hline $\begin{array}{l}\text { Rivera, Gregory \& Cobos } \\
\text { (2015) }\end{array}$ & $\begin{array}{l}\text { Technology Experience, Mobile App Utility, Attitude to } \\
\text { Mobile App, Intent to Use a Mobile App }\end{array}$ & $\begin{array}{l}\text { Attitude towards mobile } \\
\text { apps }\end{array}$ \\
\hline $\begin{array}{l}\text { Sánchez-Alzate \& } \\
\text { Montoya-Restrepo (2016) }\end{array}$ & $\begin{array}{l}\text { Seller Reputation, Perceived Risk } \\
\text { Buyer's gender, Association, Privacy, Transaction Security. }\end{array}$ & $\begin{array}{l}\text { Confidence in digital } \\
\text { media purchases }\end{array}$ \\
\hline Yeo, Goh \& Razaei (2017) & $\begin{array}{l}\text { Hedonic Motivation, Pre-Purchase Experiences Online, Time } \\
\text { Saving Guidance, Money Saving Guidance, Convenience } \\
\text { Motivation, Post-Use Utility }\end{array}$ & $\begin{array}{l}\text { Referring to online home } \\
\text { services }\end{array}$ \\
\hline $\begin{array}{l}\text { Elvyari, Sukartiko \& } \\
\text { Nugrahini (2018) }\end{array}$ & $\begin{array}{l}\text { Order Compliance, Courtesy and Kindness of Delivery Staff, } \\
\text { Food Box Cleaning, Status of Food Orders Received, } \\
\text { Affordable Delivery Costs }\end{array}$ & $\begin{array}{l}\text { Aspects that influence the } \\
\text { consumer behavior of an } \\
\text { Application }\end{array}$ \\
\hline $\begin{array}{l}\text { He, Han, Cheng, Fan \& } \\
\text { Dong (2019) }\end{array}$ & $\begin{array}{l}\text { High Quality Food, Waiting Time, Location, Preparation } \\
\text { Time, Number of Orders Accumulated }\end{array}$ & $\begin{array}{l}\text { Competitiveness buys } \\
\text { and homes online }\end{array}$ \\
\hline $\begin{array}{l}\text { Ray, Dhir, Bala \& Kaur } \\
\text { (2019) }\end{array}$ & $\begin{array}{l}\text { Customer Experience, Ease of Use } \\
\text { Restaurant Listing, Restaurant Search }\end{array}$ & ASDMR referred \\
\hline
\end{tabular}

Source: Own elaboration

Due to the lack of a previous model establishing the variables to be measured concerning attitudes towards home food delivery APPs, and about the multi-attribute model proposed by Fishbein and Ajzen (1975), this document aims to answer the following question: What is the perceived attitude of users of food home applications prepared in Bogotá City? for which it is intended to describe the concept of attitude through the multi-attribute model, to identify the consumer profile of home applications, to recognize the perceived attitude of the consumer of home applications through a multi-attribute model and the relationship between factors about the applications with the highest perceived attitude.

Due to the lack of a previous model establishing the variables to be measured concerning attitudes towards home APPs, and about the multi-attribute model proposed by Fishbein and Ajzen (1975), this document aims to answer the following question: What is the perceived attitude of users of delivery prepared food service applications in Bogotá city? Due this, it is intended to describe the concept of attitude through the multi-attribute model, to identify the consumer profile of home applications, to recognize the perceived attitude of the consumer of 


\section{$3^{\text {rd }}$ International Conference on Advanced Research in SOCIAL SCIENCES}

11-14 March, 2021

Oxford - United Kingdom

home applications through a multi-attribute model and the relationship between factors about the applications with the highest perceived attitude.

In cognitive field, attitudes are formed as a result of the individual's direct experience with the product (Grye 1999), the information received by the influence of social group, advertising, etc. (Solomon 2010), which allow the consumer to make an image of a particular product or service depending on the perception of many variables that affect it (Peter \& Olson 2006). This implies that the non-prior use of a particular brand does not limit the consumer to make a value judgment, the influence generated by the primary group has value and can therefore be sufficiently credible (López-Rodríguez, et al. 2020).

From the affective attitudes reflect emotions (Peter \& Olson 2006; Rivas \& Grye 2015), feelings (Harré, Clarke \& De Carlo 1985; Peter \& Olson 2006), moods (Izard, Kagan \& Zajonc1984) and assessments (Zajonc \& Markus 1982; Rivas \& Grye 2015), being the emotion that generates the greatest intensity and reactive response, little control and physical sensation (Peter \& Olson 2006), as well as based on particular preferences by previous paradigms of each consumer, which are verbalized under constructs of advantages and disadvantages (Zajonc \& Markus 1982; Izard, Kagan, \& Zajonc 1984; Harré, Clarke, \& De Carlo 1985).

The behavior refers to the intent to buy (Rivas \& Grye 2015), thus being, attitudes can generate the effect of consistency (Solomon 2006; Schiffman \& Kanuk 2010), that is, whose consumer makes a consumption decision, has a degree of consistency with the previous value judgment, in that sense, if the attitude is positive towards a brand, the probability that this brand will be chosen to meet the need is high (Grye 1999). However, the environmental and situational context can cause attitude to be modified for the benefit of the need to be satisfied (Grye 1999; Olavarrieta, et al. 2006), where the functional context does not necessarily take precedence over the decision and possibly social consumer contexts make a value judgment different for each case (Schiffman \& Kanuk 2010).

However, the reasoned theory of action (Ajzen \& Fishbein 1980), integrates the components of attitude, based on the context of the subjective rule, in that sense, a value judgment is oriented against the social context of consumption and purchasing situation (Ajzen \& Madden 1986), therefore, the subjective rule is a rule of behavior that is imposed in a social context (Cheung, Chan \& Wong 1999), in some cases, this pattern of behavior may dictate social acceptance by a reference group (Tarkiainen \& Sundqvist 1984). In this way, the subjective rule affects the favorability or unfavorability towards a brand, if the consumer wishes to be accepted by that group, and in some cases may be against his convictions (Ajzen 2005). Thus, the resulting attitude is the intention of consumption (Tarkiainen \& Sundqvist 1984), based on a value judgment that depends on their interests or influence (Cancino et al. 2020) and motivation around the influence group (Ajzen 1991).

On the other hand, Katz (1960) proposes that attitudes themselves can develop functions towards the consumer in such a way that they allow it to appropriate forms of behavior against some particular products and possibly generated changes in pre-established attitudes, thus being, the first function is called adjustment or adaptation, which refers to the relevance of consumer satisfaction focusing on the positive aspects of the experience of using a brand (Katz, 1960; Rivas \& Grye 2015). The second function is the defense of the self, which is characterized by the sense of trust and security that some products provide to consumers who want to compensate for aspects of their personality that seek to reaffirm their self-confidence (Katz 1960; Schiffman \& Kanuk 2010)

The third function is called expressive value, which is oriented towards the favorability of consumers towards products that reaffirm their particular beliefs and interests and diss 


\section{$3^{\text {rd }}$ International Conference on Advanced Research in SOCIAL SCIENCES}

11-14 March, 2021

Oxford - United Kingdom

favorability towards those who go against their values (Katz 1960; Solomon 2006; Rivas \& Grye 2015). The function of knowledge is based on consistency, however, the sense of structure and order in the environment is inherent to the human being and makes this function simplify the judgment of value towards a brand and it is stable over time (Katz 1960; Solomon, 2006; Schiffman \& Kanuk 2010).

\subsection{Multi-attribute attitude models}

Multi-attribute models consider attitude to the consumer as an assessment that determines the intent to purchase, in that sense, the consumer beliefs (Solomon 2006), are the cognitive component and it is the one that prevails in the evaluation, thus being in line with the dual mediation model (Schiffman \& Kanuk 2010) which relates the processes of the central route and peripheral route (Petty, Cacioppo \& Shumann 1983). The central route refers to the high involvement, thus being the consumer calls into question the evaluation of all available attributes of a given product or brand (López Rodríguez et al. 2017), while the peripheral route refers to a tangential assessment since it relates to low-involvement products, however, the dual model (Petty et al. 1983), proposes that the assessment from the perspective of the central route is influenced in one way or another by peripheral, in that sense, advertising, becomes a key aspect, affecting the evaluation of the attributes of the mark in accordance with the predisposition learned (Petty et al. 1983; Cristancho et al. 2019).

The multi-attribute model proposed by Fishbein and Ajzen (1975) measures three components of attitude: outstanding beliefs, the relationship between object and attribute, and evaluation (Ajzen \& Fishbein 1980). Outstanding beliefs are an effect the consumer's learned predisposition, in that sense, is the degree of perceived value that the consumer has or assigns to a brand or set of brands, therefore it is a mental process typical of the consumer, the relationship between the object and the attribute is the ability to relate that a mark or product has a particular attribute, these being the characteristics that the consumer takes into account when making a purchase decision. And finally, the assessment corresponds to the performance measure based on the predisposition learned, therefore, it does not necessarily imply a consumer experience.

In this sense, Fishbein and Ajzen proposed (1975) a model multiple attributes which consider that attitude (A) is the result of the sum of the product between the importance of each attribute (and the perceived performance of these that the consumer has towards an object ( $\mathrm{j}$ ), this being a brand, a product, a service, or a particular advertisement (Fishbein \& Ajzen 1975; Ajzen \& Fishbein 1977). Therefore, the set of attributes (i) is previously defined by the consumer based on their beliefs and experiences of consumption or intention of consumption, say is the cognitive component (Fishbein \& Ajzen 1975; Ajzen \& Fishbein 1977). Importance (I) is the degree of relevance that an attribute has in conjunction with the other attributes of the study object (Fishbein \& Ajzen 1975; Ajzen \& Fishbein 1977), while perceived performance, is the evaluation of each attribute (A) about the cognitive component from the affective component (Fishbein \& Ajzen 1975; Ajzen \& Fishbein 1977), the same evaluation exercise contains an emotion expressed in the positive assessment if the experience was desired generated a state of satisfaction, and negative if the experience was not satisfactory. In this sense the attitude of being able to be represented through the equation proposed by Fishbein \& Ajzen (1975):

$$
A_{i j k}=\beta_{i j k} I_{i k}
$$




\section{$3^{\text {rd }}$ International Conference on Advanced Research in SOCIAL SCIENCES}

11-14 March, 2021

Oxford - United Kingdom

Multi-attribute models allow to measure the attitude not only of an object but of a set of objects (Ajzen, 1991), i.e. marks belonging to the same category, which allows to obtain results, both individually by brand, as well as, of a set of these, for which, from a sense of diagnosis, identifies the relative advantages of each brand (Ajzen \& Madden 1986), as well as measuring the degree of relationship between an attribute and a brand perceived by the consumer (Hansen 1969), and its relative performance, therefore, is an analysis and diagnostic tool, which allows to identify the positive and negative aspects of a brand, and possibly infer about its intention to buy (Tarkiainen \& Sundqvist 1984).

\section{Method}

This study was addressed in two stages, the first was developed through a descriptive exercise with a quantitative approach, to research the analysis variables, as described by Hernandez, Fernandez, \& Baptista (2014) and obtain the aspects in consideration of mobile application users when ordering prepared food. 400 surveys were conducted with an open question, in men and women in Bogotá city, over the age of 18, who have applied for a food home prepared in the last 30 days. This instrument was implemented between April and May of 2019 and identified the existence of 9 aspects to be considered in that consumption situation.

The second stage allowed the measurement of perceived attitudes to consumers of home applications according to attitude measurement model proposed by Fishbein and Ajzen (1975). The population under study was men and women from Bogotá city, over the age of 18, who have applied for a food home prepared in the last 30 days through an application of delivery service. For this purpose, a survey was used as an information-gathering tool, this being a social technique, which allows information to be collected verbally or in writing, through a series of questions structured to a group people previously defined in front of a particular situation (Alvira, 2011), achieved 451 valid surveys.

This instrument was divided into three parts: the first presents 4 items to characterize the participating population of the study, through nominal questions of single answer. The second part presents 9 items which allow to assess the degree of importance of the related aspects in Table 2, which the consumer takes into account to use an application of domiciles, across a semantic differential scale of 1 to 9 since the model indicates that the maximum value of the scale is taken from the number of aspects to be evaluated, with 1 being important and 9 being very important. The third part consists of 36 items, in order to assess the perceived performance in the 4 application brands compared to the 9 items of the previous part, from questions type semantic differential scale 1 to 10 , being 1 lousy performance and 10 excellent performance.

Taking as a reference the valuation from bivariate correlations of Spearman's Rho statistic, it is intended to identify the degree of linear association and intensity, between two random numerical variables, as a reference, the ranges, order numbers, of each group of subjects and compares those ranges (Martínez Ortega et al. 2009), for this case, the social classes of the population studied and the related aspects in Table 2, this statistic being non-parametric and since the variables do not have a behavior related to a normal distribution (Cáceres Hernández 2006), it is considered as the appropriate.

The collection of information was carried out in the second quarter of 2019 and the validation of the instrument was developed through the Cronbach's Alpha test which is a coefficient used to assess the extent to which the items of an instrument are correlated (González-Alonso \& Pazmiño-Santacruz 2015), obtaining satisfactory results for each of the 4 brands in the 9 items of the third part of the instrument, as shown in table 3, for this the statistical package SPSS ${ }^{\circledR}$ 25.0 (Statistical Package for the Social Sciences) was used. 
 \\ $3^{\text {rd }}$ International Conference on Advanced Research in SOCIAL SCIENCES}

11-14 March, 2021

Oxford - United Kingdom

Table 3. Reliability statistics for each dimension of the instrument.

\begin{tabular}{cccc}
$\begin{array}{c}\text { Instruments } \\
\text { dimensions }\end{array}$ & Cronbach's Alpha & $\begin{array}{c}\text { Cronbach's Alpha based } \\
\text { on standardized elements }\end{array}$ & $\begin{array}{c}\text { Number of } \\
\text { elements }\end{array}$ \\
\hline Rappi & 0.906 & 0.915 & 9 \\
Domicilios.com & 0.926 & 0.931 & 9 \\
Uber Eats & 0.939 & 0.943 & 9 \\
I Food & 0.937 & 0.941 & 9 \\
\hline
\end{tabular}

Source: Own elaboration

\section{Results and Discussion}

The sample of this study is characterized as 50,8\% (n:229) women and 49,2\% (n:222) men, similar to the normal distribution gender in Colombia. Most of the participant's age is between 20 to 29 years old $(63,2 \%$ n: 285$)$, belonging to working $(32,6 \%)$ and lower middle class (46,8\%), incomes between 1 to 3 minimum Colombian salary (MCS), and all of them stated that they had used a mobile application of food delivery service in the last month., the descriptive data of this population are related in table 4.

Table 4. Characterization of the population

\begin{tabular}{cccc}
\hline Variable & Items & $\begin{array}{c}\text { Frequency } \\
(\mathbf{n = 4 5 1})\end{array}$ & Percentage \\
\hline \multirow{2}{*}{ Genre } & Masculine & 222 & 49.2 \\
& Feminine & 229 & 50.8 \\
& $20-24$ & 168 & 37.3 \\
\multirow{4}{*}{ Age } & $25-29$ & 117 & 25.9 \\
& $30-34$ & 71 & 15.7 \\
& $35-39$ & 51 & 11.3 \\
& $40-44$ & 25 & 5.5 \\
Stratus & $45-49$ & 19 & 4.2 \\
& 2 & 147 & 32.6 \\
& 3 & 211 & 46.8 \\
& 4 & 67 & 14.9 \\
Income & 5 & 26 & 5.8 \\
& Less than 1 MCS to 1 MCS & 120 & 26.6 \\
& between 1 MCS to 3 MCS & 269 & 59.6 \\
& between 3 MCS to 6 MCS & 53 & 11.8 \\
More than 6 MCS & 9 & 2 \\
\hline
\end{tabular}

Remark: SMMLV (current legal monthly minimum wages) Minimum payment in Colombia Source: Own elaboration

In the first instance, the aspects that habitual consumers of home applications considered to choose an application were identified, among which it is highlighted that the most frequent are the home delivery's speed, discounts and promotions, presentation of the product and the delivery service cost, aspects that are part of the value offer of the applications, leaving in a second instance aspects related to the offer of restaurants and the presentation of the domiciliary, this relationship is evidenced in table 5.

Table 5. Aspects to consider when choosing a home application

\begin{tabular}{llc}
\hline \multicolumn{1}{c}{ Aspects } & \multicolumn{1}{c}{ Authors } & $\%$ \\
\hline Speed of home delivery & Daim, et al (2013); Yeo, Goh \& Razaei (2017) & $14,8 \%$ \\
Discounts and promotions & Elvyari, Sukartiko \& Nugrahini (2018) & $13,3 \%$ \\
Presentation of the product & Elvyari, Sukartiko \& Nugrahini (2018); He, et al. (2019) & $12,8 \%$
\end{tabular}




\section{$3^{\text {rd }}$ International Conference on Advanced Research in SOCIAL SCIENCES}

11-14 March, 2021

\section{Oxford - United Kingdom}

\begin{tabular}{|c|c|c|}
\hline Aspects & Authors & $\%$ \\
\hline Home cost & $\begin{array}{l}\text { Yeo, Goh \& Razaei (2017), Elvyari, Sukartiko \& } \\
\text { Nugrahini (2018) }\end{array}$ & $11,3 \%$ \\
\hline $\begin{array}{l}\text { Ease of use of the } \\
\text { application }\end{array}$ & $\begin{array}{l}\text { Wang et al. (2006), Kim, Park \& Morrison (2008), } \\
\text { Rivera, Gregory \& Cobos (2015), Ray et al. (2019) }\end{array}$ & $10,0 \%$ \\
\hline $\begin{array}{l}\text { Security against the means } \\
\text { of payment }\end{array}$ & $\begin{array}{l}\text { Bhatnagar, Misra \& Rao (2000), Wang et al. (2006), } \\
\text { Sánchez-Alzate \& Montoya-Restrepo (2016) }\end{array}$ & $10,0 \%$ \\
\hline Coverage & He et al. (2019), Ray et al. (2019) & $10,0 \%$ \\
\hline $\begin{array}{l}\text { Offer of recognized } \\
\text { restaurants }\end{array}$ & Ray et al. (2019) & $9,3 \%$ \\
\hline $\begin{array}{l}\text { Presentation of the } \\
\text { domiciliary }\end{array}$ & $\begin{array}{l}\text { Sánchez-Alzate \& Montoya-Restrepo (2016), Elvyari, } \\
\text { Sukartiko \& Nugrahini (2018) }\end{array}$ & $8,8 \%$ \\
\hline
\end{tabular}

According to the Fishbein \& Ajzen (1975) model, were found nine relevant items, in order of importance are, defined in table 5, was identified, the most important being the home delivery's speed and the security concerning of means payment; and those of lower importance was the delivery person appearance and the discounts and promotions. On the other hand, it was identified that the average valuation of all items for all brands was less than 6.0 is a lower than acceptable rating in terms of performance. In that regard, the Rappi brand (A-257.94) domicilios.com and (A-257.39) obtained the highest weighted values, thus being the most attitude perceived brands, instead, the UberEats (229.87) and IFood (193.46) brands with the lowest attitude perceived, the average valuation of the latter two is below 5.0. According to these results, the brand with the best attitude ranking is Rappi, the results of the application of the model are related in table 6 .

Table 6. Results vs. Fishbein and Ajzen Model.

\begin{tabular}{|c|c|c|c|c|c|c|c|c|c|}
\hline Item & Imp. & Rappi & $\begin{array}{l}\text { Assessment } \\
\text { Rappi }\end{array}$ & Domicilios.com & $\begin{array}{l}\text { Assesment } \\
\text { Domicilios.com }\end{array}$ & $\begin{array}{l}\text { Uber } \\
\text { Eats }\end{array}$ & $\begin{array}{l}\text { Assessment } \\
\text { Uber Eats }\end{array}$ & IFood & $\begin{array}{l}\text { Assessment } \\
\text { iFood }\end{array}$ \\
\hline $\begin{array}{l}\text { Offer of renowned } \\
\text { restaurants }\end{array}$ & 5 & 5.95 & 29.73 & 5.82 & 29.12 & 5.13 & 25.65 & 4.12 & 20.58 \\
\hline $\begin{array}{l}\text { Ease of use of the } \\
\text { application }\end{array}$ & 4 & 5.92 & 23.66 & 5.76 & 23.03 & 5.12 & 20.48 & 4.20 & 16.80 \\
\hline Home delivery's speed & 9 & 5.67 & 51.05 & 5.48 & 49.34 & 5.07 & 45.60 & 4.22 & 37.97 \\
\hline $\begin{array}{l}\text { Security in the means of } \\
\text { payment }\end{array}$ & 8 & 5.87 & 46.92 & 5.80 & 46.41 & 5.15 & 41.17 & 4.27 & 34.19 \\
\hline Product appearance & 6 & 5.73 & 34.39 & 5.75 & 34.47 & 5.10 & 30.61 & 4.36 & 26.15 \\
\hline Home delivery cost & 3 & 5.68 & 17.04 & 5.82 & 17.47 & 5.08 & 15.25 & 4.42 & 13.27 \\
\hline Sales & 2 & 5.65 & 11.31 & 5.82 & 11.63 & 4.89 & 9.78 & 4.52 & 9.03 \\
\hline Range & 7 & 5.47 & 38.31 & 5.74 & 40.19 & 5.16 & 36.15 & 4.44 & 31.05 \\
\hline $\begin{array}{l}\text { The delivery person } \\
\text { appearance }\end{array}$ & 1 & 5.51 & 5.51 & 5.74 & 5.74 & 5.19 & 5.19 & 4.42 & 4.42 \\
\hline Attitude assessment & & & 257.94 & & 257.39 & & 229.87 & & 193.46 \\
\hline
\end{tabular}

Source: Own elaboration

According to Spearman's bilateral Rho correlation between the social class and the aspects to be considering to choose of an application of home delivery app's was found bilateral significance for the Rappi brands and domicilios.com both less than 0.05, these are the most perceived brands according to the Fishbein and Ajzen model (1975). Referring to Rappi brand, the significance is present in 5 items: product appearance, home delivery cost, discounts and promotions, availability of restaurants with coverage, and presentation of the home; while for the brand- it was present in 6 items: ease of use of the application, security against the means 


\section{$3^{\text {rd }}$ International Conference on Advanced Research in SOCIAL SCIENCES}

11-14 March, 2021

Oxford - United Kingdom

of payment, presentation of the product, cost of domicile, discounts and promotions, availability of restaurants with coverage.

In table 7 , it is noted that a statistically significant, weak, and directly proportional linear relationship was found for the Rappi brand, between the social class and the product presentation ( $\mathrm{rS}-0.154, \mathrm{p}<0.01)$, the cost of delivery $(\mathrm{rS}-0.142, \mathrm{p}<0.01)$, discounts and promotions $(\mathrm{rS}-0.119, \mathrm{p}<0.05)$, coverage $(\mathrm{rS}-0.156, \mathrm{p}<0.01)$, and home delivery $(\mathrm{rS}-0.125$, $\mathrm{p}<0.01)$ in-home application users, thus having a meaningful relationship is not relevant to the social class.

However, there is a statistically significant, strong and directly proportional linear relationship between product presentation and home cost $(\mathrm{rS}-0.805, \mathrm{p}<0.01)$, moderate and directly proportional to discounts and promotions $(\mathrm{rS}-0.723, \mathrm{p}<0.01)$ as well as coverage $(\mathrm{rS}-0.565$, $\mathrm{p}<0.01$ ); and finally weak and directly proportional to the presentation of the home address ( $\mathrm{rS}$ $0.455, \mathrm{p}<0.01$ ), this implies that there is consistency whose relevance is in the presentation of the products with the other items.

Similar results are obtained that show a statistically significant linear relationship, strong and directly proportional between the cost of home and discounts and promotions ( $\mathrm{rS}-0.832$, $\mathrm{p}<0.01$ ), moderate and directly proportional to coverage (rS-0.643, $\mathrm{p}<0.01$ ) and home filing $(\mathrm{rS}-0.455, \mathrm{p}<0.01)$. While there is a statistically significant, moderate, and directly proportional linear relationship between discounts and promotions and with coverage $(r S-0.707, p<0.01)$ and the presentation of the home address $(\mathrm{rS}-0.584, \mathrm{p}<0.01)$. Finally, there is a statistically significant, moderate, and directly proportional linear relationship between coverage and delivery person appearance $(\mathrm{rS}-0.584, \mathrm{p}<0.01)$.

Table 7. Statistical results of association between the stratum and the items consider in the choice of an application of domiciles for the Rappi brand.

\begin{tabular}{|c|c|c|c|c|c|c|c|}
\hline & Spearman's Rho & Stratus & $\begin{array}{c}\text { Product } \\
\text { presentation }\end{array}$ & $\begin{array}{c}\text { Cost of } \\
\text { delivery }\end{array}$ & $\begin{array}{c}\text { Discounts and } \\
\text { promotions }\end{array}$ & Range & $\begin{array}{c}\text { Domiciliary } \\
\text { presentation }\end{array}$ \\
\hline \multirow{3}{*}{ Social class } & Correlation coefficient & 1.000 & $.154^{* *}$ & $.142^{* * *}$ & $.119^{*}$ & $.156^{* * *}$ & $.125^{* *}$ \\
\hline & Sig. (bilateral) & & 0.001 & 0.003 & 0.011 & 0.001 & 0.008 \\
\hline & $\mathrm{N}$ & & 451 & 451 & 451 & 451 & 451 \\
\hline \multirow{3}{*}{$\begin{array}{l}\text { Product } \\
\text { appearance }\end{array}$} & Correlation coefficient & & 1.000 & $.805^{* *}$ & $.723^{* *}$ & $.565^{* * *}$ & $.455^{* *}$ \\
\hline & Sig. (bilateral) & & & 0.000 & 0.000 & 0.000 & 0.000 \\
\hline & $\mathrm{N}$ & & & 451 & 451 & 451 & 451 \\
\hline \multirow{3}{*}{$\begin{array}{l}\text { Cost of } \\
\text { delivery }\end{array}$} & Correlation coefficient & & & 1.000 & $.832^{* *}$ & $.643^{* *}$ & $.532^{* *}$ \\
\hline & Sig. (bilateral) & & & & 0.000 & 0.000 & 0.000 \\
\hline & $\mathrm{N}$ & & & & 451 & 451 & 451 \\
\hline \multirow{3}{*}{$\begin{array}{l}\text { Discounts } \\
\text { and } \\
\text { promotions }\end{array}$} & Correlation coefficient & & & & 1.000 & $.707^{* *}$ & $.584^{* *}$ \\
\hline & Sig. (bilateral) & & & & & 0.000 & 0.000 \\
\hline & $\mathrm{N}$ & & & & & 451 & 451 \\
\hline \multirow{3}{*}{ Range } & Correlation coefficient & & & & & 1 & $.671^{* *}$ \\
\hline & Sig. (bilateral) & & & & & & 0.000 \\
\hline & $\mathrm{N}$ & & & & & & 451 \\
\hline Delivery & Correlation coefficient & & & & & & 1.000 \\
\hline person & Sig. (bilateral) & & & & & & \\
\hline appearance & $\mathrm{N}$ & & & & & & \\
\hline
\end{tabular}

Note: **. The correlation is meaningful at level 0.01 (bilateral), *. The correlation is significant at level 0.05 (bilateral).

Source: Own elaboration

Table 8 shows the bivariate correlations for the brand Domicilios.com, finding a statistically significant, sparsely and directly proportional linear relationship between the social class and the ease of use of the application $(\mathrm{rS}-0.109, \mathrm{p}<0.05)$, security of means of payment $(\mathrm{rS}-0.141$, 


\section{$3^{\text {rd }}$ International Conference on Advanced Research in SOCIAL SCIENCES}

11-14 March, 2021

Oxford - United Kingdom

$\mathrm{p}<0.01)$, product appearance $(\mathrm{rS}-0.101, \mathrm{p}<0.05)$, delivery cost $(\mathrm{rS}-0.125, \mathrm{p}<0.01)$, discounts and promotions $(\mathrm{rS}-0.141, \mathrm{p}<0.01)$, and coverage $(\mathrm{rS}-0.125, \mathrm{p}<0.01)$, in-home application users, therefore despite the existence of a significant relationship is not relevant to the social class.

However, there is a statistically significant, high, and directly proportional linear relationship between the ease of use of the application and security against the means of payment $(\mathrm{rS}-0.835$, $\mathrm{p}<0.01$ ), as well as moderate and directly proportional to the presentation of the product (rS$0.681, \mathrm{p}<0.01)$ and the cost of domicile $(\mathrm{rS}-0.551, \mathrm{p}<0.01)$, and finally weak and directly proportional to discounts and promotions ( $\mathrm{rS}-0.477, \mathrm{p}<0.01)$ and coverage $(\mathrm{rS}-0.305, \mathrm{p}<0.01)$. In this sense, the consistency between factors is present when the ease of use of the application is relevant to the other aspects that influence the choice of application.

Therefore, the results are similar, with a statistically significant, high and directly proportional linear relationship between safety versus the means of payment and the presentation of the product $(\mathrm{rS}-0.839, \mathrm{p}<0.01)$, moderate and directly proportional to the cost of domicile ( $\mathrm{rS}$ $0.690, \mathrm{p}<0.01)$ and discounts and promotions ( $\mathrm{rS}-0.601, \mathrm{p}<0.01)$, and weak and directly proportional to coverage $(\mathrm{rS}-0.456, \mathrm{p}<0.01)$. In this sense, a statistically significant, moderate, and directly proportional linear relationship was found between product presentation and home cost ( $\mathrm{rS}-0.796, \mathrm{p}<0.01)$, discounts, and promotions ( $\mathrm{rS}-0.719, \mathrm{p}<0.01)$, and coverage ( $\mathrm{rS}-0.541$, $\mathrm{p}<0.01)$.

As well as a statistically significant, high, and directly proportional linear relationship between the cost of domicile and discounts and promotions ( $\mathrm{rS}-0.842, \mathrm{p}<0.01)$, moderate and directly proportional to coverage ( $\mathrm{rS}-0.682, \mathrm{p}<0.01)$. Finally, a statistically significant, moderate, and directly proportional linear relationship was found between discounts and promotions and coverage $(\mathrm{rS}-0.728, \mathrm{p}<0.01)$.

Table 8. Statistical results of association between the stratum and the items consider in the choice of an application of domiciles for the brand domicilios.com

\begin{tabular}{|c|c|c|c|c|c|c|c|c|}
\hline \multicolumn{2}{|c|}{ Spearman's Rho } & Stratus & $\begin{array}{l}\text { Applicatio } \\
\text { n use ease }\end{array}$ & $\begin{array}{l}\text { Payment } \\
\text { security }\end{array}$ & $\begin{array}{l}\text { Product } \\
\text { presentation }\end{array}$ & $\begin{array}{l}\text { Cost of } \\
\text { delivery }\end{array}$ & $\begin{array}{l}\text { Discounts and } \\
\text { promotions }\end{array}$ & Range \\
\hline \multirow{3}{*}{ Social class } & Correlation coefficient & 1.000 & $.109^{*}$ & $.141^{* *}$ & $.101^{*}$ & $.125^{* * *}$ & $.141^{* *}$ & $.125^{* *}$ \\
\hline & Sig. (bilateral) & & 0.02 & 0.003 & 0.032 & 0.008 & 0.003 & 0.008 \\
\hline & $\mathrm{N}$ & & 451 & 451 & 451 & 451 & 451 & 451 \\
\hline \multirow{3}{*}{$\begin{array}{l}\text { Application } \\
\text { use ease }\end{array}$} & Correlation coefficient & & 1.000 & $.835^{* *}$ & $.681^{* *}$ & $.551^{* *}$ & $.477^{* *}$ & $.305^{* *}$ \\
\hline & Sig. (bilateral) & & & 0.000 & 0.000 & 0.000 & 0.000 & 0.000 \\
\hline & $\mathrm{N}$ & & & 451 & 451 & 451 & 451 & 451 \\
\hline \multirow{3}{*}{$\begin{array}{l}\text { Payment } \\
\text { security }\end{array}$} & Correlation coefficient & & & 1.000 & $.839^{* * *}$ & $.690^{* *}$ & $.601^{* * *}$ & $.456^{* * *}$ \\
\hline & Sig. (bilateral) & & & & 0.000 & 0.000 & 0.000 & 0.000 \\
\hline & $\mathrm{N}$ & & & & 451 & 451 & 451 & 451 \\
\hline \multirow{3}{*}{$\begin{array}{l}\text { Product } \\
\text { appearance }\end{array}$} & Correlation coefficient & & & & 1.000 & $.796^{* *}$ & $.719^{* * *}$ & $.541^{* * *}$ \\
\hline & Sig. (bilateral) & & & & & 0.000 & 0.000 & 0.000 \\
\hline & $\mathrm{N}$ & & & & & 451 & 451 & 451 \\
\hline \multirow{3}{*}{ Delivery cost } & Correlation coefficient & & & & & 1.000 & $.842^{* *}$ & $.682^{* * *}$ \\
\hline & Sig. (bilateral) & & & & & & 0.000 & 0.000 \\
\hline & $\mathrm{N}$ & & & & & & 451 & 451 \\
\hline \multirow{3}{*}{$\begin{array}{l}\text { Discounts } \\
\text { and } \\
\text { promotions }\end{array}$} & Correlation coefficient & & & & & & 1.000 & $.728^{* *}$ \\
\hline & Sig. (bilateral) & & & & & & & 0.000 \\
\hline & $\mathrm{N}$ & & & & & & & 451 \\
\hline \multirow{3}{*}{ Range } & Correlation coefficient & & & & & & & 1.000 \\
\hline & Sig. (bilateral) & & & & & & & \\
\hline & $\mathrm{N}$ & & & & & & & \\
\hline
\end{tabular}

Note: **. The correlation is meaningful at level 0.01 (bilateral), *. The correlation is significant at level 0.05 (bilateral).

Source: Own elaboration 


\section{$3^{\text {rd }}$ International Conference on Advanced Research in SOCIAL SCIENCES}

11-14 March, 2021

Oxford - United Kingdom

\section{Discussion}

From a theoretical perspective, attitude is a basic psychological function of people that allows to make value judgments against anything, however, being associated with consumption situations makes the value judgment representative against a product or brand, thus being, the cognitive and emotional component are present and generate an effect on the consumer. These value judgments are consistent with the consumer experience or the effect of the influence generated by the most relevant influence groups for the consumer, or even the same advertising leading to an image between what is acceptable or not acceptable to that consumer.

Therefore, the cognitive component allows to develop evaluations to minimize subjectivity based on the proposal of Fishbein \& Ajzen (1975), since it allows to assess by the consumer based on the expectations generated by brands based on the characteristics or attributes of the products perceived by the east (Lopez-Rodriguez, et al, 2020); in this sense, the experience of consumption and influence, become the validator of those expectations, for which, the emotional component is the one that verbalizes and sentences the valuation.

In this regard, attitude in the consumer becomes a relevant aspect of the decision process, due it is implicitly including previous processes such as perception, memory, motivation, and of course the degree of satisfaction. For this reason, the consistency as a representative aspect of the attitude is associated not only from the final valuation of each brand and its probability of choice, but from all aspects perceived by the consumer, since it values all individually, but from an overall perspective of each brand.

Thus, from the exercise developed for the applications brands of representative home delivery food service of Bogotá city, it was possible to identify the aspects or attributes perceived by that consumer and that it considers it relevant to choose an application, among which it is worth noting that speed in delivery of the domicile, security against the means of payment and coverage are the most important things.

Thereby, the category has average ratings below 6.0 of a rating 1 to 10 , where 1 is poor and 10 excellent, therefore, generally the category has a low rating in performance, which allows inferring that the level of satisfaction perceived by consumers is not optimal compared to the use of any home application. It is the highlight, that the two brands with the highest perceived attitude are those that have been the longest on the market, with valuations in each aspect between 5.4 and 5.9; while the two brands with the shortest time on the market have ratings of between 4.1 and 5.2 getting a lower final perception in terms of attitude.

In this sense, it can be inferred that the longest-time brand in the market has a better perception, which allows brands to develop more communication actions and therefore greater impact in terms of positioning, as well as favors informing consumer imaginaries in those who do not consume in that application which can become favorable given the media impact that brands generate in the media, as well as the visualization of the domiciles by the city of Bogotá, promoting a better attitude perceived by the consumer.

\section{Conclusions}

Taking into account the results obtained under Spearman's Rho correlation coefficient, it is inferred that for the most perceived brands there is a weak relationship between the stratum and the aspects to take into account when choosing an application of domiciles and that relationship is associated with the economic context of each consumer. However, for the Rappi brand, there is a relationship between its aspects, for which, for which the consumer gives relevance to the presentation of the product this directly will associate it with the costs arising from the service, the presence of promotions or discounts, and the coverage area of the home since the greater 


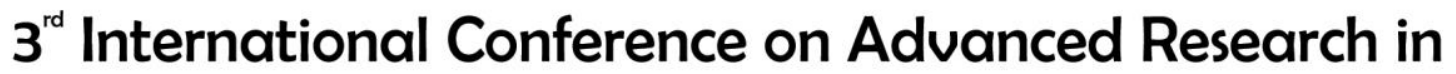 SOCIAL SCIENCES
}

\author{
11-14 March, 2021
}

Oxford - United Kingdom

the collection of the domicile; and a weak relationship with the presentation of the home address being this aspect the second-lowest rated in the attitude measurement.

For the domiciles.com brand, the relationship between the aspects is given by the ease of use of the application, since the application is exclusive for restaurant homes, which allows the consumer to have a greater perception of security against the means of payment and against the certainty of obtaining a product similar to that seen by the application. Similarly, you can see the relationship between the cost of the domicile and the coverage area since the restaurant directly allocates its area of influence according to the location of its retail establishments in the city, whose distribution of products most of the time does so through its own home homes. On the other hand, the discounts offered by the application are typical of the establishment of commerce, in that sense, reaffirms the perception of security to the payment, thus being the cost of domicile and the discounts are the aspects with the highest score compared to the measurement of the attitude for the brand domicilios.com.

It is relevant to take into account for future research, to apply the multi-attribution model proposed by Fishbein \& Ajzen (1975) in different brands and product categories to observe its relevance and validation in different consumer contexts, as well as it is relevant to develop models that allow to measure the functions of attitudes, as well as from reasoned theory of action to understand how the sociocultural context is a relevant factor when choosing a product, and from the perception of a brand by the social consumption responsible for the platforms that take as a framework of operation models of the collaborative economy, aspects to be taken into account for the measurement of attitude.

\section{References}

[1]. Alvira, M. F. (2011). La encuesta: Una perspectiva general metodológica. Madrid: Centro de Investigaciones Sociológicas.

[2]. Ajzen, I. \& Fishbein, M. (1977). Attitude-behavior relations: a theoretical analysis and review of empirical research. Psychological Bulletin, 84(5), 888-918.

[3]. Ajzen, I. \& Fishbein, M. (1980). Understanding attitudes and predicting social behavior. Englewood Cliffs, New Jersey: Prentice-Hall.

[4]. Ajzen, I. \& Madden, Y. J. (1986). Prediction of global-directed behavior: Attitudes, intentions and perceived behavioral control. Journal of Experimental Social Psychology, 22, 453-474.

[5]. Ajzen, I. (1991). The theory of Planned Behavior. Organizational Behavior and Human Decision Process, 50, 179-211.

[6]. Bhatnagar, A., Misra, S., \& Rao, H. R. (2000). On risk, convenience, and Internet shopping behavior. Communications of the ACM, 43(11), 98-105.

[7]. Cáceres Hernández, J. J. (2006). Conceptos básicos de estadística para ciencias sociales. Las Rozas, Madrid: Delta Publicaciones.

[8]. Cancino, Y.A., Cristancho, G.J., Palacios, J., Carrillo, J., Castro, M. \& Paez, J. (2020). Comparación del comportamiento del consumidor en tiendas de descuento duro y grandes superficies. Revista Espacios. 41(7), 15-23.

[9]. Cheung, S. F., Chan, K. S. \& Wong, S. Y. (1999). Reexamining the theory of planned behavior in understanding wastepaper recycling. Environment and Behavior, 31(5), 587612.

[10]. Cristancho, G.J., Cancino, Y.A., Palacios, J. \& Manjarrez C.I. (2019). Brand positioning as a factor in the choice of the candidate for higher education. Revista Espacios. 40(41), 3644. 


\section{$3^{\text {rd }}$ International Conference on Advanced Research in SOCIAL SCIENCES}

11-14 March, 2021

Oxford - United Kingdom

[11]. Daim, T. U., Basoglu, A. N., Gunay, D., Yildiz, C., \& Gomez, F. (2013). Exploring technology acceptance for online food services. International Journal of Business Information Systems, 12(4), 383-391.

[12]. Dinero (2019). Los nuevos reyes de los domicilios de comida. Recovered from https://www.dinero.com/edicion-impresa/negocios/articulo/plataformas-para-pedircomida-a-domicilio-en-colombia/266802

[13]. El Tiempo (2019). Mientras Rappi recibe gran inversión, Domicilios.com cambia de jefe. Recovered from https://www.eltiempo.com/economia/empresas/las-cifras-de-rappi-ydomicilios-com-357224

[14]. Fishbein, M. \& Ajzen, I. (1975). Belief, attitude, intention and behaviour: An introduction to theory and research. Reading, Mass: Addison-Wesley Pub. Co.

[15]. Grande, I. (1999). Las actitudes de los consumidores mayores ante la compra y sus consecuencias sobre la gestión de marketing. Estudios sobre consumo, 14 (51), 53-66.

[16]. González-Alonso, J. \& Pazmiño-Santacruz, M. (2015). Cálculo e interpretación del Alfa de Cronbach para el caso de validación de la consistencia interna de un cuestionario, con dos posibles escalas tipo Likert. Revista Publicando (2), 62-67.

[17]. Hansen, F. (1969). Consumer choise behavior: An experimental approach. Journal of Marketing Research, (6), 436-443.

[18]. Harré, R., Clarke, D., \& De Carlo, N. (1985). Motives and Mechanisms. London: Routledge.

[19]. He, Z., Han, G., Cheng, T. C. E., Fan, B., \& Dong, J. (2019). Evolutionary food quality and location strategies for restaurants in competitive online-to-offline food ordering and delivery markets: An agent-based approach. International Journal of Production Economics, 215, 61-72.

[20]. Hernandez, S. R., Fernandez, C. C., \& Baptista, L. M. (2014). Metodología de la investigación. México: McGraw-Hill.

[21]. Institucional Colombia. (s.f.). Top de las 4 mejores aplicaciones para pedir comida a domicilio en Colombia. Recovered from https://www.institucionalcolombia.com/top-de-las4-mejores-aplicaciones-para-pedir-comida-a-domicilio-en-colombia/

[22]. Izard, C. E., Kagan, J., \& Zajonc, R. B. (1984). Emotions, cognition, and behavior. Cambridge. Cambridge University Press

[23]. Katz, D. (1960). The functional approach to the study of attitudes. Public Opinion Quarterly. 24, 163 -204.

[24]. Kim, D. J., Ferrin, D. L. \& Rao, H. R. (2008). A trust-based consumer decision-making model in electronic commerce: The role of trust, perceived risk, and their antecedents. Decision Support Systems. 44, (2), 544-564.

[25]. Kim, D.Y., Park, J. \& Morrison, A.M. (2008). A model of traveller acceptance of mobile technology. International Journal of Tourism Research, 10(5), 393-407.

[26]. Kung, L. C., \& Zhong, G. Y. (2017). The optimal pricing strategy for two-sided platform delivery in the sharing economy. Transportation Research Part E: Logistics and Transportation Review, 101(23), 1-12.

[27]. La República (2018). Domicilios.com y Rappi son los reyes en el negocio de los pedidos. Recovered from https://www.larepublica.co/empresas/las-aplicacionesdomicilioscom-y-rappi-son-los-reinas-en-el-negocio-de-pedidos-2787087

[28]. Lopez-Rodriguez, C. E., Cristancho-Triana, G. J., \& Amaya-Tellez, J. L. (2020). Perception and Desired Brand Personality in Organizations that Internationalize Services: 


\section{$3^{\text {rd }}$ International Conference on Advanced Research in SOCIAL SCIENCES}

11-14 March, 2021

Oxford - United Kingdom

The Case of the Colombian Business Environment. European Research Studies Journal, 23(3), 581-597.

[29]. Martínez Ortega, R. M., Tuya Pendás, L. C., Pérez Abreu, A., \& Cánovas, A. M. (2009). El coeficiente de correlación de los rangos de Spearman caracterización. Revista Habanera de Ciencias Médicas, 8(12), 34-52.

[30]. Ministerio de Tecnologìas de la información y Comunicación (2018). Boletín trimestral de las TIC's 2018. Recovered from https://colombiatic.mintic.gov.co/679/articles82350 presentacion_cifras.pdf

[31]. Moon, Y., \& Armstrong, D. J. (2019). Service quality factors affecting customer attitudes in online-to-offline commerce. Information Systems and e-Business Management, $18(1), 1-34$.

[32]. Olavarrieta, S., Hidalgo, P., Manzur, E., \& Farias, P. (2006). Riesgo percibido y la actitud hacia las marcas privadas. Revista Latinoamericana de Administración, 37, 73-89.

[33]. Pendrous, R. (2006). Global data exchange system shows huge growth. Food Manufacture, 81(7), 24-35.

[34]. Persaud, A. \& Azhar, I. (2012). Innovative mobile marketing via smartphones: Are consumers ready? Marketing Intelligence \& Planning, 30(4), 418-443.

[35]. Peter, J. P., \& Olson, J. C. (2006). Comportamiento del consumidor y estrategia de marketing. México, D.F: McGraw-Hill.

[36]. Petty, R., Cacioppo, J., \& Shumann, D. (1983). Central and Peripheral Routes to Advertising Effectiveness: The Moderating Role of Involvement. Journal of Consumer Research, 10(16), 135-146.

[37]. Pigatto, G., Machado, J., Negreti, A. \& Machado, L. (2017). Have you chosen your request? Analysis of online food delivery companies in Brazil. British Food Journal, 119(3), 639-657.

[38]. Ray, A., Dhir, A., Bala, P. K., \& Kaur, P. (2019). Why do people use food delivery apps (FDA)? A uses and gratification theory perspective. Journal of Retailing and Consumer Services, 51, 221-230.

[39]. Rivas, J. \& Grande, I. (2015). Comportamiento del consumidor. Decisiones y estrategia de marketing. Madrid: Alfaomega.

[40]. Rivera, M., Gregory, A. \& Cobos, L. (2015). Mobile application for the timeshare industry: The influence of technology experience, usefulness, and attitude on behavioral intentions. Journal of Hospitality and Tourism Technology, 6(3), 242-257.

[41]. Sánchez-Alzate, J. \& Montoya-Restrepo, L. (2016). Factores que afectan la confianza de los consumidores por las compras a través de medios electrónicos. Pensamiento \& gestión 15(40), 159-183

[42]. Schiffman, L. G., \& Kanuk, L. (2010). Consumer behavior. Harlow, United Kingdom: Pearson Education Limited.

[43]. Sjahroeddin, F. (2018, October). The Role of ES-Qual and Food Quality on Customer Satisfaction in Online Food Delivery Service. In Prosiding Industrial Research Workshop and National Seminar, 9(23), 551-558.

[44]. Suki, N. M. (2011). A structural model of customer satisfaction and trust in vendors involved in mobile commerce. International Journal of Business Science \& Applied Management, 6(2), 18-30.

[45]. Solomon, M. (2006). Comportamiento del consumidor. México: Pearson Education

[46]. Tarkiainen, A., \& Sundqvist, S. (1984). Subjective Norms, Attitudes and Intentions of Finnish Consumers in Buying Organic Food. British Food Journal, 107, 808-822. 


\section{CarSS SOCIAL SCIENCES \\ $3^{\text {rd }}$ International Conference on Advanced Research in 11-14 March, 2021

\section{Oxford - United Kingdom}

[47]. Wang, Y.-S., Lin, H.-H., \& Luarn, P. (2006). Predicting consumer intention to use mobile service. Information Systems Journal, 16(2), 157-179.

[48]. Yeo, Vincent \& Goh, See Kwong \& Rezaei, Sajad. (2017). Consumer experiences, attitude and behavioral intention toward online food delivery (OFD) services. Journal of Retailing and Consumer Services. 35(18), 150-162.

[49]. Zajonc, R. B., \& Markus, H. (1982). Affective and Cognitive Factors in Preferences. Journal of Consumer Research, 9(2), 123-131. 